\title{
Cardiac Cachexia and Its Impact on Survival in Heart Failure Patients
}

\author{
Aninka Saboe' ${ }^{1}$, Badai B. Tiksnadi ${ }^{1}$, Augustine Purnomowati', Toni M. Aprami
}

Department of Cardiology and Vascular Medicine, Padjadjaran University
Background. Cardiac cachexia (CC) is one of indicator of poor prognosis in heart failure. Unfortunately, its existence is often overlooked by many cardiologists, this is further complicated by small number of study concerning CC, and the controversial issues they encompasses.

Methods. The aim of this study is to analyze the survival in heart failure (HF) patients with cachexia complications. A retrospective cohort study was conducted on the data from Hasan Sadikin General Hospital HF registry from March 2013 - August 20 I4. The inclusion criteria was the data registry (registry's inclusion criterias: HF patients above 18 years of age with left ventricle ejection fraction (LVEF) below $40 \%$, time onset of HF more than 6 months and exclusion criterias were valvular diseases as primary etiology of HF). The exclusion criteria was if the patients have other chronic disease (COPD, CKD, cancer). Cardiac cachexia was diagnosed in patients fulfilling the criteria from international cachexia consensus.

Results. There were 39 patients, most of them were female (6I.5\%), with mean LVEF $28.5 \%$ (⒍7). Cardiac cachexia was diagnosed in 6 (15.3\%) patients. At 6 months of follow-up after initial enrollment, the cumulative rate of death from cardiovascular cause was $83 \%$ among cachectic as compared $37.5 \%$ among noncachectic patients $\mathrm{p}=0.00$ I Adjusted $\mathrm{HR}(95 \% \mathrm{Cl})$ $=8.05(2.40-27.04)$. There were no association between mortality with sex $(p=0.268)$, etiology of HF $(p=0.288)$, LVEF $(p=0.06 \mathrm{I})$, comorbid condition (hypertension $p=0.237$, diabetes mellitus $p=0.163$ ).

Conclusions. We conclude that patients with cardiac cachexia is independent predictor of death in HF and warrants a special consideration in the management of HF.

(J Kardiol Indones. 20I5;36:69-74)

Keywords: Cardiac cachexia, heart failure, survival analysis 
Jurnal

Kardiologi Indonesia

J Kardiol Indones. 2015;36:69-74

ISSN $0126 / 3773$

\title{
Cardiac Cachexia dan Dampaknya terhadap Sintasan Penderita Gagal Jantung
}

\author{
Aninka Saboe, Badai B. Tiksnadi, Augustine Purnomowati, Toni M. Aprami
}

\begin{abstract}
Latar belakang Cardiac cachexia (CC) merupakan salah satu indikator prognosis yang buruk dari gagal jantung, namun sebagian besar dari klinisi masih belum menyadari pentingnya dan besarnya dampak yang ditimbulkan oleh CC. Hal tersebut juga dipersulit dengan penelitian mengenai CC yang masih jarang dan masih banyaknya hal - hal mengenai CC yang masih kontroversial. Tujuan penelitian adalah menganalisa sintasan antara penderita gagal jantung yang menderita komplikasi CC. Metode Penelitian retrospektif kohort menggunakan data yang diambil secara konsekutif dari registri Heart Failure (HF) dilakukan di RSUP Hasan Sadikin dari Maret 2013 - Agustus 2014. Kriteria inklusi adalah semua data dari registri HF (kriteria inklusi registri: usia diatas 18 tahun, ejeksi fraksi < 40\%, waktu menderita gagal jantung lebih dari 6 bulan dengan kriteria eksklusi adalah kelainan katup sebagian penyebab primer). Kriteria eksklusi adalah bila penderita memiliki kondisi kronik lain (PPOK, gagal ginjal kronik, kanker). Diagnosis CC ditegakkan menggunakan kriteria konsensus cachexia internasional.

Hasil Jumlah penderita yang memenuhi kriteria adalah 39 penderita, sebagian besar adalah perempuan (61.5\%) dengan rata - rata fraksi ejeksi 28.5\% (†6.7). Diagnosa CC ditegakkan pada 6 penderita (15.3\%). Follow up 6 bulan dilakukan dan angka kematian yang disebabkan oleh kardiovaskuler terjadi pada $83 \%$ penderita cachexia sedangkan pada penderita tanpa cachexia adalah $37.5 \%, \mathrm{p}=0.001$. Adjusted $\mathrm{HR}(95 \% \mathrm{CI})=8.05(2.40-27.04)$. Tidak ada asosiasi antara kematian dengan jenis kelamin $(\mathrm{p}=0.268)$, etiologi gagal jantung $(\mathrm{p}=0.288)$, ejeksi fraksi $(\mathrm{p}=0.061)$ atau kondisi komorbid (hipertensi $\mathrm{p}=0.237$, diabetes mellitus $\mathrm{p}=0.163$ ).

Kesimpulan Cardiac cachexia merupakan prediktor kematian yang tidak tergantung pada faktor lainnya dan membutuhkan perhatian khusus dari klinisi dalam tatalaksana penderita gagal jantung.
\end{abstract}

(J Kardiol Indones. 2015;36:69-74)

Kata kunci: cardiac cachexia, gagal jantung, analisa sintasan

\author{
Alamat Korespondensi \\ Dr. Aninka Saboe, Departemen Kardiologi dan Kedokteran Vaskular, \\ Universitas Padjadjaran \\ Tel / Email : aninsaboe@gmail.com
}

\section{Pendahuluan}

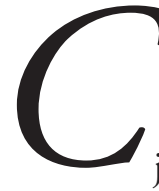

achexia jantung merupakan salah satu komplikasi gagal jantung yang serius. ${ }^{1,}$

${ }^{2} \mathrm{Hal}$ ini disebabkan karena cachexia jantung merupakan salah satu indikator prognosis buruk pada penderita gagal jantung yang tidak tergantung pada parameter prognosis yang lain, seperti usia, kelas fungsional New York Heart Association (NYHA), fraksi ejeksi ventrikel kiri, atau 
konsumsi oksigen maksimal. ${ }^{1,3,4}$ Angka kematian penderita gagal jantung yang mengalami cachexia lebih tinggi dibandingkan penderita gagal jantung yang tidak mengalami cachexia. ${ }^{5}$ Sejauh ini, belum ada penelitian mengenai analisa sintasan pada cardiac cachexia. Penelitian ini bertujuan untuk menganalisa sintasan pada cardiac cachexia agar dapat meningkatkan kepedulian para dokter untuk lebih serius dalam menangani gagal jantung dan juga menjadi dorongan untuk melakukan penelitian lebih lanjut mengenai cardiac cachexia.

\section{Metode}

Penelitian retrospektif kohort menggunakan data yang diambil secara konsekutif dari registri Heart Failure dilakukan di RSUP Hasan Sadikin dari Maret 2013 Agustus 2014. Kriteria inklusi adalah semua data dari registri Heart Failure (kriteria inklusi dari registri adalah: usia diatas 18 tahun, fungsi ejeksi ventrikel kiri kurang dari $40 \%$, dan penderita gagal jantung simtomatik dengan diagnosa gagal jantung yang ditegakkan lebih dari 6 bulan setelah episode dekompensasi gagal jantung pertama yang menyebabkan perawatan rumah sakit atau sebagai penderita rawat jalan dengan kriteria eksklusi dari registri adalah kelainan katup primer sebagai penyebab gagal jantung). Kriteria eksklusi adalah bila penderita memiliki kondisi kronik lain seperti gagal ginjal kronik, penyakit paru obstruktif kronik, dan kanker. Faktor komorbid yang dinilai adalah hipertensi dan Diabetes Mellitus.

Tabel 1. Kriteria Diagnosis Cachexia

\begin{tabular}{ll}
\hline No. & Kriteria Diagnosis \\
\hline 1 & Dasar penyakit kronis \\
2 & Penurunan berat badan $>5 \%$ dalam 12 bulan \\
& Atau \\
& Indeks Massa Tubuh $<20 \%$ \\
3 & Terdapat minimal 3 dari 5 kriteria: \\
& a. Penurunan kekuatan otot \\
b. Lemah & c. Anoreksia \\
d. Indeks massa bebas lemak yang rendah \\
e. Gangguan biokimia \\
- Inflamasi \\
- Anemia \\
- Kadar albumin serum yang rendah
\end{tabular}

Keterangan: Harus memenuhi keseluruhan 3 kategori diatas untuk menegakkan diagnosis cachexia.
Kriteria diagnosa cardiac cachexia ditegakkan menggunakan konsensus cachexia internasional.

Hipertensi ditegakkan pada penderita dengan tekanan darah $\geq 140 / 90 \mathrm{mmHg}$ atau sedang dalam pengobatan hipertensi. Diabetes Mellitus ditegakkan pada penderita dengan gula darah puasa $\geq 126 \mathrm{mg} /$ $\mathrm{dL}$, gula darah 2 jam post prandial $\geq 200 \mathrm{mgdL}$, atau penderita dengan gejala kardinal diabetes mellitus (polidipsia, poliuria, polifagia, penurunan berat badan), atau penderita yang sedang dalam terapi pengobatan Diabetes Mellitus.

Penderita kemudian dibagi menjadi 2 kelompok, yaitu kelompok gagal jantung tanpa cachexia dan kelompok gagal jantung dengan cachexia. Follow up kemudian dilakukan selama 6 bulan untuk melihat hasil luaran yaitu kematian yang disebabkan oleh penyebab kardiovaskuler yang kemudian akan dianalisa secara statistik.

Analisa statistik yang dilakukan adalah analisis bivariat dengan menggunakan menggunakan Uji Chi Kuadrat atau untuk data kategorik dan Uji T atau Mann Whitney untuk data numerik, analisa multivariat menggunakan log rank statistic dan kurva Kaplan Meier survival. Analisa lebih lanjut dilakukan dengan Cox regression. Kalkulasi dengan Kaplan Meier event rates dilakukan pada 6 bulan. Pelaporan menggunakan Hazard ratio dengan 95\% Confidence interval. P values kurang dari 0.05 dianggap memiliki nilai statistik yang signifikan. Analisis menggunakan software SPSS.

\section{Hasil}

Penderita yang memenuhi kriteria inklusi dan eksklusi adalah sebanyak 39 penderita yang kemudian dibagi menjadi 2 kelompok penelitian, yaitu penderita dengan dan tanpa cardiac cachexia.

Dari tabel 2 dapat dilihat karakteristik dasar pada penderita yang mengikuti penelitian. Tidak terdapat perbedaan signifikan antara kedua kelompok, kecuali pada jenis kelamin $(\mathrm{p}=0.024)$, berat badan $(\mathrm{p}=0.002)$ dan indeks massa tubuh $(\mathrm{p}<0.001)$. Indeks massa tubuh dan berat badan merupakan salah satu kriteria dalam penegakkan diagnosis cardiac cachexia.

Tabel 3 menunjukan asosiasi antara kematian dengan cardiac cachexia $(\mathrm{p}=0.016)$ dan itdak ada asosiasi antara kematian dengan jenis kelamin $(\mathrm{p}=0.268)$, etiologi gagal jantung $(\mathrm{p}=0.288)$, ejeksi fraksi $(\mathrm{p}=0.061)$ atau kondisi komorbid (hipertensi $\mathrm{p}=0.237$, diabetes mellitus $\mathrm{p}=0.163$ ). 
Tabel 2. Karakteristik dasar subyek penelitian

\begin{tabular}{|c|c|c|c|}
\hline & $\begin{array}{l}\text { CC } \\
n=6\end{array}$ & $\begin{array}{c}\text { Non CC } \\
n=33\end{array}$ & Nilai $\mathrm{p}$ \\
\hline Umur & $49 \pm 17$ & $59 \pm 9$ & 0.199 \\
\hline \multicolumn{4}{|l|}{ Jenis kelamin } \\
\hline Pria & $5(83.3)$ & $10(30.3)$ & 0.024 \\
\hline Wanita & $1(16.7)$ & $23(69.7)$ & \\
\hline \multicolumn{4}{|l|}{ NYHA FC } \\
\hline I & $0(0.0)$ & $1(3.0)$ & 0.463 \\
\hline II & $2(33.3)$ & $21(63.6)$ & \\
\hline III & $3(50.0)$ & $9(27.3)$ & \\
\hline IV & $1(16.7)$ & $2(6.1)$ & \\
\hline Tinggi badan $(\mathrm{m})$ & $1.55 \pm 0.06$ & $1.60 \pm 0.08$ & 0.140 \\
\hline Berat badan $(\mathrm{kg})$ & $44 \pm 4$ & $59 \pm 11$ & 0.002 \\
\hline $\begin{array}{l}\text { Indeks massa tubuh } \\
(\mathrm{kg} / \mathrm{m} 2)\end{array}$ & $18.39 \pm 0.89$ & $23.10 \pm 3.18$ & $<0.001$ \\
\hline \multicolumn{4}{|l|}{ Etiologi } \\
\hline CAD & $1(16.7)$ & $19(57.6)$ & 0.181 \\
\hline DCM & $2(33.3)$ & $6(18.2)$ & \\
\hline HHD & $3(50.0)$ & $8(24.2)$ & \\
\hline \multicolumn{4}{|l|}{ Lama gagal jantung } \\
\hline$<1$ tahun & $1(16.7)$ & $16(48.5)$ & 0.461 \\
\hline $1-5$ tahun & $4(66.7)$ & $12(36.4)$ & \\
\hline 5-10 tahun & $1(16.7)$ & $4(12.1)$ & \\
\hline$>10$ tahun & $0(0.0)$ & $1(3.0)$ & \\
\hline Hipertensi & $5(83.3)$ & $18(54.5)$ & 0.370 \\
\hline Diabetes Mellitus & $2(33.3)$ & $4(12.1)$ & 0.224 \\
\hline Ejeksi Fraksi (\%) & $32.98 \pm 6.48$ & $27.67 \pm 6.56$ & 0.075 \\
\hline
\end{tabular}

Keterangan: NYHA FC (New York Heart Association Functional Class), CAD (Coronary artery disease), DCM (Dilated Cardiomyopathy), HHD (Hypertensive heart disease)

Dengan menggunakan bantuan software SPSS, analisis survival Kaplan-Meier menghasilkan median survival untuk CC sebesar 3.5 bulan. Uji kebermaknaan dengan logrank test menghasilkan nilai $\mathrm{p}<0.001$ dan Crude HR (95\% CI) $=50.95$ (6.98 - 372.08). Uji dengan Cox Regresi menghasilkan nilai $\mathrm{p}=0.001$ dan Adjusted HR $(95 \% \mathrm{CI})=8.05(2.40-27.04)$ dengan melibatkan faktor perancu (DM, Hipertensi dan EF). Ini artinya bahwa setiap saat kelompok cardiac cachexia beresiko untuk meninggal 8 kali dibanding kelompok tanpa cardiac cachexia
Tabel 3. Asosiasi antara Kematian akibat Kardiovaskuler dalam 6 bulan dengan cardiac cachexia dan kondisi lain

\begin{tabular}{lccc}
\hline & $\begin{array}{c}\text { Meninggal } \\
\mathrm{n}=14\end{array}$ & $\begin{array}{c}\text { Hidup } \\
\mathrm{n}=25\end{array}$ & Nilai p \\
\hline Cardiac cachexia & & & \\
- Ya & $5(35.7)$ & $1(4.0)$ & $\mathbf{0 . 0 1 6}$ \\
- Tidak & $9(64.3)$ & $24(96)$ & \\
\hline Jenis Kelamin & & & \\
- Laki - laki & 7 & 8 & 0.268 \\
- Perempuan & 7 & 17 & \\
\hline Etiologi & & & \\
- CAD & $1(48.0)$ & $12(57.1)$ & 0.288 \\
- DCM & $1(7.1)$ & $7(28.0)$ & \\
- HHD & $5(35.7)$ & $6(24.0)$ & \\
\hline Hipertensi & $10(71.4)$ & $13(52.0)$ & 0.237 \\
- Ya & $4(28.6)$ & $12(48.0)$ & \\
- Tidak & $4(28.6)$ & $2(8.0)$ & 0.163 \\
\hline Diabetes Mellitus & $10(71.4)$ & $23(92.0)$ & \\
- Ya & 23.85 & 30 & 0.061 \\
- Tidak & $(18.1-39.2)$ & $(12.4-38.0)$ & \\
\hline Ejeksi Fraksi & & & \\
& & &
\end{tabular}

Keterangan: HT: hipertensi, DM: Diabetes Mellitus, EF: ejeksi fraksi

\section{Diskusi}

Kami menyimpulkan pada penelitian ini bahwa cardiac cahexia merupakan prediktor kematian yang tidak tergantung pada faktor lainnya. Selain itu, kelompok cardiac cachexia memiliki risiko untuk kematian akibat gangguan kardiovaskuler yang sangat tinggi dibandingkan kelompok tanpa cardiac cachexia, yaitu 8 kali lebih berisiko dengan median survival 3.5 bulan. Hasil penelitian yang menunjukan dampak cardiac cachexia yang sangat besar pada sintasan penderita gagal jantung sangat tidak terduga oleh peneliti namun sangat disayangkan masih banyak faktor - faktor dalam cardiac cachexia yang masih kontroversial, yaitu dalam kriteria definisi, penegakkan diagnosis, dan tatalaksana.

Tabel 4. Analisis Survival antara Cardiac cachexia dengan kematian

\begin{tabular}{lccccc}
\hline & Median Survival & Crude HR $(95 \%$ CI $)$ & Nilai p & Adjusted HR (95\% CI) & Nilai p \\
\hline CC & 3.5 & $50.95(6.98-372.08)$ & $<0.001$ & $8.05(2.40-27.04)$ & 0.001 \\
Non CC & - & & & & \\
\hline
\end{tabular}

Keterangan: Crude HR tidak melibatkan kondisi komorbid, nilai p di uji dengan logrank test. Adjusted HR dengan melibatkan kondisi komorbid (DM, Hipertensi, dan EF), nilai p di uji dengan cox regresi 


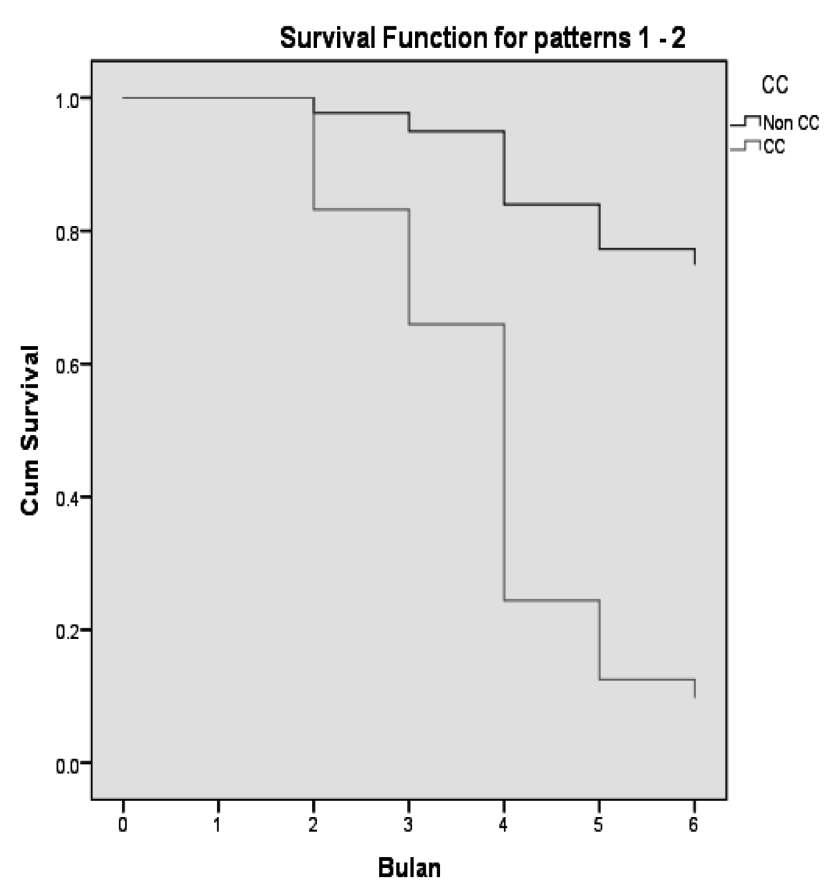

Grafik 1. Analisa Survival antara penderita cardiac cachexia dengan tanpa cardiac cachexia

Definisi cachexia jantung belum disepakati secara umum hingga saat ini, sehingga menyebabkan penegakkan diagnosis menjadi cukup rumit dan menyebabkan perbedaan - perbedaan hasil baik dalam segi epidemiologi, karakteristik dan prognosis dari cardiac cachexia. ${ }^{3,6}$ McMurray,dkk menyatakan bahwa penderita dengan gagal jantung kongestif dapat dikategorikan telah menderita cachexia jantung bila kandungan lemak tubuh pada wanita kurang dari 29\% atau pada laki-laki kurang dari 27\%. Penelitian lain menganjurkan definisi cachexia jantung adalah adanya penurunan berat badan penderita gagal jantung saat kondisi penderita gagal jantung tidak edema sebesar lebih dari 6\% yang terjadi selama lebih dari 6 bulan dan terdokumentasi. ${ }^{7}$ Anker,dkk mengemukakan definisi cachexia jantung yang lebih mudah digunakan, yaitu penderita dengan gagal jantung kongestif yang tidak memiliki kondisi medis lain yang dapat menyebabkan keadaan cachexia dengan penurunan berat badan lebih $7,5 \%$ dari berat badan normal sebelum sakit yang terjadi lebih dari 6 bulan. ${ }^{8}$ Penelitian ini menggunakan kriteris definisi cardiac cachexia dari konsensus cachexia internasional. Definisi cardiac cachexia yang seragam dan mudah sangat diperlukan agar para klinisi dapat mengidentifikasi cardiac cachexia dengan baik.
Tatalaksana dan pencegahan cardiac cachexia belum ada sampai saat penelitian ini dilakukan. Terapi cardiac cachexia masih berdasarkan patofisiologi dari gagal jantung namun belum ada yang terbukti berhasil. Cardiac cachexia merupakan komplikasi dari gagal jantung dengan hasil akhir penyusutan massa tubuh, baik massa otot, tulang dan lemak. Terdapat berbagai macam jalur mekanisme dalam proses penyusutan tubuh, yang sebagian besar diantaranya merupakan jalur yang teraktivasi pada awal gagal jantung, yaitu aktivasi dari sistem neurohormonal dan sistem inflamasi yang merupakan awal perjalanan cariac cachexia..$^{3,9,10}$

Penelitian ini diharapkan dapat menjadi landasan untuk penelitian - penelitian lain dengan skala besar baik untuk pencegahan maupun terapi dari cardiac cachexia yang belum ada sampai saat ini.

\section{Daftar Pustaka}

1. Georgiadou P, Adamopoulos S. Skeletal muscle abnormalities in chronic heart failure. Curr Heart Fail Rep. 2012 Jun;9(2):12832. PubMed PMID: 22430147. Epub 2012/03/21. eng.

2. Farkas J, von Haehling S, Kalantar-Zadeh K, Morley J, Anker S, Lainscak M. Cachexia as a major public health problem: frequent, costly, and deadly. Journal of Cachexia, Sarcopenia and Muscle. 2013 2013/09/01;4(3):173-8. English.

3. von Haehling S, Doehner W, Anker SD. Nutrition, metabolism, and the complex pathophysiology of cachexia in chronic heart failure. Cardiovascular research. 2007 January 15, 2007;73(2):298-309.

4. Anker SD, Ponikowski P, Varney S, Chua TP, Clark AL, WebbPeploe KM, et al. Wasting as independent risk factor for mortality in chronic heart failure. The Lancet. 1997;349(9058):1050-3.

5. Anker SD, Laviano A, Filippatos G, John M, Paccagnella A, Ponikowski P, et al. ESPEN Guidelines on Parenteral Nutrition: on cardiology and pneumology. Clin Nutr. 2009 Aug;28(4):45560. PubMed PMID: 19515464. Epub 2009/06/12. eng.

6. Martins T, Vitorino R, Amado F, Duarte JA, Ferreira R. Biomarkers for cardiac cachexia: reality or utopia. Clin Chim Acta. 2014 Sep 25;436:323-8. PubMed PMID: 24978823. Epub 2014/07/01. eng.

7. Anker SD, Negassa A, Coats AJ, Afzal R, Poole-Wilson PA, Cohn JN, et al. Prognostic importance of weight loss in chronic heart failure and the effect of treatment with angiotensinconverting-enzyme inhibitors: an observational study. Lancet. 2003 Mar 29;361(9363):1077-83. PubMed PMID: 12672310. Epub 2003/04/04. eng.

8. Anker SD, Steinborn W, Strassburg S. Cardiac cachexia. Ann 
Jurnal Kardiologi Indonesia

Med. 2004;36(7):518-29. PubMed PMID: 15513302. Epub 2004/10/30. eng.

9. Anker SD, von Haehling S. Inflammatory mediators in chronic heart failure: an overview. Heart. 2004;90(4):464-70. PubMed PMID: PMC1768165.
10. Doehner W, Frenneaux M, Anker SD. Metabolic Impairment in Heart Failure: The Myocardial and Systemic Perspective. Journal of the American College of Cardiology. 2014 Sep 30;64(13):1388-400. PubMed PMID: 25257642. Epub 2014/09/27. Eng. 